\title{
Trochę się zazdrości tym, co nie dożyli tych czasów... Dziennik Ludwiki Ostrowskiej z Maluszyna, oprac. Jarosław Kita i Piotr Zawilski, Naczelna Dyrekcja Archiwów Państwowych, Warszawa 2014, ss. 189.
}

$\mathrm{H}$ istorycy w ostatnich latach do rąk czytelników dostarczają owoce swoich długoletnich prac badawczych dotyczących dziejów jednostki funkcjonującej w określonej przestrzeni historycznej. Jednostka, jej wewnętrzne przemiany powodowane przez impulsy zewnętrzne, jej życiowe zwycięstwa i porażki, jej postawy i kultywowane przez nią wzorce, stanowią ciekawe spojrzenie na szersze zagadnienia z życia politycznego, gospodarczego czy społecznego w danej epoce historycznej. Takie spojrzenie w swoisty sposób „uczłowiecza historię”, wyrywa dzieje z liczb, schematów czy norm. Na owe biografie składa się warsztat badawczy oraz indywidualna interpretacja historyka, któremu nie sposób wyzbyć się pewnego subiektywizmu. Mimo wykorzystywania przez badaczy szeregu dokumentów prywatnych poczynając od pamiętników (w badaniach biograficznych będących swoistą ikoną, biorącą przewagę nad innymi źródłami do badań nad życiorysem ludzi z dawnych epok), poprzez korespondencję z członkami rodziny czy przyjaciółmi, na przypadkowo zachowanych notatkach, kończąc. Coraz częściej również na ten dorobek badawczy składają się badania z dziedziny psychologicznej czy socjologicznej i razem z warsztatem historyka tworzą holistyczny obraz badanej rzeczywistości. Czytelnik przyjmuje zaprezentowane zestawienie faktów, gdyż jest one rzetelne. W związku z szerokim podejściem do tematu odbiorca treści nie decyduje się na własną, amatorską próbę interpretacji. Przy źródłach dotyczących pojedynczych jednostek oraz ogólnej wiedzy na temat czasów, w których żył potencjalny bohater, próba własnej prezentacji postaci, przy ogólnej wiedzy na temat epoki, zapewne przystawałaby do ówczesnych realiów. Takie działania osób nie związanych naukowo z historią mogłyby stanowić ciekawe wyzwanie badawcze i być najlepszą formą spotkania $\mathrm{z}$ historią. Dlatego też historia wychodzi do ludzi interesujących się przeszłością i dostarcza gotowe materiały (po często żmudnej pracy całego zespołu znawców przy odczytywaniu rękopisów) w oryginalnym brzmieniu swoim czytelnikom. Takie podejście do tematu stanowi swoiste wyzwanie dla historii, gdyż o interpretacje źródeł może pokusić się każdy i nie zawsze wnioski zbudowane na bazie kontaktu ze źródłem mogą być słuszne. Mimo tych obaw warto udostępnić ogółowi oryginalny 
materiał. W razie ochrony prawdy historycznej, do której powinno się przybliżać, zalecać obudowanie owych źródeł bazą naukowych opracowań w celu stworzenia swoistego tła historycznego. W parze z prezentowanym wyżej podejściem idą ostatnie trendy naukowej historii zmierzające do badania dziejów codzienności, które z oczywistych względów są dla „amatorów historii” bardziej przystępne, a nierzadko ciekawsze.

W ramach zeszłorocznych obchodów setnej rocznicy wybuchu pierwszej wojny światowej Archiwa Państwowe podjęły liczne inicjatywny mające na celu upamiętnienie tego jakże istotnego momentu dla historii państwowości polskiej. Wśród tych inicjatyw znalazła się seria wydawnicza zatytułowana Wielka Wojna - codzienność niecodzienności. Celem powyższego przedsięwzięcia było ukazanie tożsamościowych postaw Polaków w tych trudnych, ale zarazem pełnych nadziei czasach. Materiałami źródłowymi spełniającymi owe wymagania były pamiętniki, dzienniki czy listy prywatne. Spośród licznych propozycji, dokonano wyboru i jako pierwszy ukazał się dziennik Ludwiki Ostrowskiej z Maluszyna. Nienaturalne wydaje się przedstawienie zdarzeń z czasów wojny z perspektywy kobiety. Pozorne przeczucie zostanie zburzone po zapoznaniu się z krótkim życiorysem postaci, a zwłaszcza z jej biegłym władaniem piórem, tak lekkim, ale zarazem dokładnym i ekspresyjnym, który zagościł na kartach jej pamiętnika.

Dziennik Ludwiki Ostrowskiej z Maluszyna był pisany przez ponad rok. Pierwszy wpis zawidniał pod datą 30 lipca 1914 r., zaś ostatni w 8 października $1915 \mathrm{r}$. Zapiski były sporządzane regularnie, chociaż nie każdego dnia. Niekiedy autorka spisywała swoje wrażenia dzień po dniu, czasami na nową refleksję trzeba było czekać ponad tydzień. Nieproporcjonalna jest również długość poszczególnych zapisek, od kilku zdań po zapis na całej stronicy. Owa nieregularność przejawia się również w poruszanej tematyce, gdzie impulsem do pisania są wydarzenia wojenne lub prywatne. Podstawę wydania stanowi dziennik Ludwiki Ostrowskiej z Maluszyna, którego rękopis znajduje się w zbiorach Archiwum Państwowego w Łodzi, w zespole podworskim Archiwum Potockich i Ostrowskich z Maluszyna. O atrakcyjności recenzowanej publikacji świadczy dodatkowo Wstęp, w którym znajduje się Przedmowa Naczelnego Dyrektora Archiwów Państwowych, Przedsłowie Rady Naukowej, w której głos zabrali redaktorzy naukowi serii wydawniczej: Jerzy Kochanowski, Grzegorz Leszczyński i Grzegorz Mędykowski oraz Wstep z bogatymi informacjami na temat rodu Ostrowskich z Maluszyna, którego autorami są redaktorzy tomu - Jarosław Kita i Piotr Zawilski. Publikacja została dodatkowo wzbogacona o fotografie samej autorki, członków jej rodziny i krewnych. Tekst został opatrzony przypisami rzeczowymi mającymi rozszyfrować niejednoznacznie brzmiące dla czytelnika pojęcia, miejsca czy wydarzenia z epoki oraz powinowactwo członków rodziny względem głównej bohaterki. Powyższa tematyka została również nakreślona poprzez tablice genealogiczną i mapę okolic Maluszyna. Tytuł powyżej publikacji Trochę się zazdrości tym, co nie dożyli tych 
czasów... Dziennik Ludwiki Ostrowskiej z Maluszyna został wyrwany z kontekstu. Wybrzmiał na kartach dziennika bohaterki dnia 18 kwietnia 1915 r. i brzmiał:

Rocznica śmierci mojego brata Augusta. Trochę się zazdrości tym, co nie dożyli tych czasów. To znów prosi się Boga, by dał przetrwać wszystko. To nielogiczne, ale naturalna mieszanina uczuć.

Kim była autorka pamiętnika? Ludwika Aleksandra Józefa Zofia Ostrowska, ziemianka rodem z Maluszyna nad Pilicą, przyszła na świat 5 września $1851 \mathrm{r}$. jako najmłodsza z sześciorga dzieci Aleksandra hr. Ostrowskiego herbu Korab (1810-1896) i Heleny hr. Morstin herbu Leliwa (1815-1892). Jej ojciec był postacią nader znaną, zaliczał się do członków grupy klemensowczyków, propagujących na ziemiach polskich działania zmierzające do modernizacji rolnictwa i struktury społecznej, pod patronatem hr. Andrzeja Zamoyskiego. Dzięki znacznej wiedzy i swoim literackim zdolnościom wszedł w grono twórców organu prasowego propagującego powyższe idee „Roczników Gospodarstwa Krajowego”. Należał do ścisłego grona założycieli Towarzystwa Rolniczego, w którym pełnił rolę wiceprezesa. W czasie przedpowstaniowym popierał wzorce postępowania zniewolonego narodu względem caratu propagowane przez Aleksandra hr. Wielopolskiego, których był orędownikiem nawet po ustąpieniu tegoż. Za swoją lojalistyczną postawę często był nagradzany państwowymi posadami m.in. był członkiem Komitetu Obywatelskiego, Rady Stanu, gubernatorem radomskim cywilnym, a także dyrektorem w Komisji Rządowej Spraw Wewnętrznych. Za zasługi został odznaczony Orderem Św. Stanisława I klasy, Orderem Św. Anny I klasy oraz niechlubnym Medalem za uśmierzenie powstania styczniowego. Powyższe odznaczenia zaborcy nie wpłynęły na odbiór zaprezentowanej wyżej postaci wśród własnego środowiska, gdzie zyskał głównie poważanie na polu wzorcowego gospodarowania własnym majątkiem. Formalnym dowodem świadczącym o środowiskowym zaufaniu było powierzenie mu stanowiska prezesa Komitetu Kredytowego Ziemskiego w latach 1874-1890. Aleksander Ostrowski jako przedstawiciel ziemiaństwa nie stronił od swojej służebnej roli względem biedniejszych i działał na polu dobroczynnym oraz charytatywnym.

Ludwika Ostrowska miała czterech braci i jedną siostrę (brat Konrad zmarł przedwcześnie zanim jeszcze urodziła się autorka dziennika, 1846-1848). Najstarszy brat August (1836-1898) ożenił się z Elżbietą Niezabitowską h. Lubicz. Następna w kolejności starszeństwa siostra Maria (1838-1925) wyszła za mąż za Stanisława Jana Potockiego h. Złota Pilawa, dziedzica Praszki i Moskorzewa. Bracia Jan Leon (1840-1918) i Józef (1850-1923) wybrali stan kawalerski. Wszyscy bracia ukończyli studia wyższe, a zdobytą wiedze skrzętnie wykorzystywali przy modernizacji rodowych dóbr, m.in. August prowadził wzorcową stadninę koni, a Jan Leon zarządzał cukrownią w Silniczce. Józef był jednym z braci Ludwiki, który najbardziej zaangażował się w świat polityki. W 1905 r. został prezesem 
Stronnictwa Polityki Realnej, należał do twórców Polskiej Macierzy Szkolnej, a w latach 1906-1910 był wybierany do Dumy Państwowej. Ukoronowaniem jego kariery politycznej była posada w Radzie Regencyjnej Królestwa Polskiego w 1917 r.

Środowisko, z jakiego wywodziła się bohaterka dziennika, warunkowało system jej wychowania. Bazowało ono na kształceniu domowym polegającym głównie na nauce pisania, czytania, kaligrafii, historii ojczystej i powszechnej, a także lekcji „dobrego smaku”, tj. śpiewu, tańca, rysunku, haftu czy jazdy konnej. Ludwika władała kilkoma językami obcymi: francuskim, angielskim, niemieckim, rosyjskim oraz łaciną. Talent lingwistyczny kształtowany był przez głośne czytanie w czasie tzw. „szarej godziny” oraz zagraniczne podróże do Wiednia, Rzymu czy Paryża. Najbardziej zagadkową sprawą z życiorysu bohaterki wydaje się sprawa wyboru stanu panieńskiego, w którym bohaterka pozostawała całe swoje życie. Ludwika Ostrowska na fotografiach prezentuje się jako dosyć atrakcyjna kobieta, a dodatkowo dziedziczka pokaźnych dóbr, co dodatkowo potęguje chęć rozszyfrowania zagadki. Odpowiedzi na to pytanie nie znajdujemy niestety w znanych nam źródłach. Po opuszczeniu domu rodzinnego przez starszą siostrę Marię, a następnie po śmierci matki, Ludwika została panią i gospodynią na maluszyńskich dobrach. Szczególnie ze spraw gospodarskich interesowała się sadownictwem. Swoimi doświadczeniami z tej dziedziny dzieliła się na łamach specjalistycznego czasopisma „Ogrodnik Polski”. Przejmując funkcję pani domu bohaterka zaangażowała się w życie w Maluszynie od zarządzania domem, poprzez rozdzielanie obowiązków między służbę, po drobiazgowe ustalanie codziennego jadłospisu. Naturalnie jej powinnością było doglądanie hodowli drobiu. Warto również wspomnieć o eksperymentalnych próbach hrabiny uprawiania lnu w swoim kompleksie.

Mimo tych licznych obowiązków Ludwika nie stroniła od angażowania się w życie korporacyjne swojej okolicy. Znamiennym tego dowodem był udział w stowarzyszeniach dobroczynnych: Oddziału Towarzystwa Czerwonego Krzyża w Radomsku, Towarzystwa Dobroczynności dla Chrześcijan w Radomsku, Rady Opiekuńczej Szpitala w Maluszynie czy Warszawskiego Towarzystwa Ochrony Kobiet. Aktywną postawę prezentowała również przy tworzeniu kółka ziemiańskiego w Silniczce „Praca” (przy współudziale z Teresą Siemieńską). W 1905 r. była jedną z założycielek Ziemiańskiego Koła Ziemianek. Dziedziczka z Maluszyna posiadał również talent literacki i publicystyczny, pisywała m. in. do „Tygodnika Ilustrowanego” czy „Świata Kobiecego”. Była ona również autorką wierszy wychwalających piękno Maluszyna, a także podjęła się czynu spisania autorskiej interpretacji dziejów starożytnych i średniowiecznych. Próbą generalną przed stworzeniem dzieła, które prezentuje recenzowana pozycja był dzienniczek z lat młodzieńczych (1869-1871) traktujący głównie o podziale ról w rodzinie ziemiańskiej. Po śmierci brata Józefa w 1923 r. Ludwika sporządziła testament, 
w którym jedyną spadkobierczynią uczyniła siostrzenicę Helenę Potocką. „Ciocia Lulcia” (tak była nazywana w kręgu najbliższych) zmarła 24 kwietnia 1926 r. i formalnie kompleks majątkowy Ostrowskich h. Korabitów przeszedł we władanie chrząstowskiej linii Pilawitów Potockich.

Ludwika Ostrowska była wierzącą katoliczką, działaczką społeczną i zaradną gospodynią. Taki obraz bohaterki wyłania się z pożółkłych kart jej dziennika. Po pierwsze miejsce, z którego na wojnę spogląda ziemniaka - Maluszyn - był punktem, przez który przemierzały wojska ze wschodu na zachód i na odwrót oraz miejscem, gdzie schronienie znajdowali zwycięscy i pokonani. Niezmienny przez cały okres wojny w okolicach Maluszyna był jedynie obraz krzątającej się gospodyni, dbającej o każdego człowieka w potrzebie. Dla „Pani na Maluszynie” nie ma podziału na wrogów i sprzymierzeńców, wszyscy w jej oczach są po prostu ludźmi, których należy napoić, nakarmić, użyczyć kąta do spania. Często na kartach kajecika Ludwiki przewijają się zwroty:

Żywiliśmy 10 oficerów i dwudziestu rozmaitych funkcjonariuszy. (...) W pierwszej partii mamy generałów Neugebauera i Riesnera z 25 oficerami. W drugiej dowodzącego generała von Scholtza ze sztabem 50 oficerów, oprócz niezliczonej ilości rozlokowanej po wsi.

Taka postawa i zwroty błagalne na kartkach pamiętnika są najdobitniejszym dowodem na jej głęboką wiarę

W ręku Boga jesteśmy i ufność w nim pokładamy, ale serce drży o wszystkich swoich i o ten kraj nieszczęśliwy, roztratowany na wszystkich granicach. (...) Zaczyna wstępować nadzieja, że Matka Boża i teraz oswobodzi nas od potopu i pokój upragniony prędzej sprowadzi, niż można się było spodziewać.

Charakterystyczne dla bohaterki jest poczucie szerszego sensu swojego istnienia, który na łamach dziennika przyjmuje prywatny wymiar patriotycznego poświęcenia. Owo przekonanie osadzone zostało w osobistym przekonaniu o służebnej roli klas wyższych względem ogółu społeczeństwa i wynikające z powyższego obowiązki służby publicznej. Na samym początku wyraża zatroskanie o los dzieci żołnierzy, którzy udali się na wojnę:

Z naszej służby idzie Antoni Jakubowski, stróż ogrodowy, zostawiając żonę i trójkę dzieci, Jan górnik, stróż kuchenny - 5 dzieci, Wiśniewski, stróż folwarczny - 5 dzieci.

Ciągle zadręczają bohaterkę myśli o braku informacji ze stolicy:

Co to się będzie dziać pod Warszawą i jaki los jej będzie? (...) Od czterech dni żyjemy w oczekiwaniu wiadomości o wypadkach pod Warszawą. (...) O Warszawie nic nie słychać. (...) Z pewnością wzięta dotąd, bo byśmy o tym od zwycięzców wiedzieli. (...) W ogóle wiadomości bardzo skąpe, gazet nie roznoszą prawie - czy nie wolno? I to daje do myślenia. 
Znamienne jest, że bohaterka w obawie przed zagoszczeniem głodu w swoim majątku, po chwili problem ten nobilituje do skali całych ziem polskich, nie mogąc wyzbyć się owej ziemiańskiej misji względem narodu polskiego i troski o jego byt („A teraz zaczyna się okres głodu dla wielu, a trudności wielkich dla nas"). Z opisami ruchu wojsk przeplatają się informacje o przemieszczeniach członków rodziny, z kwaterunkiem we dworze towarzyska gościna znajomych.

Życie w czasie wojny rysuje się jako obraz niezwykle groteskowy, z jednej strony dzieje się okrutna rzecz, a z drugiej człowiek pędzi wraz z codziennością do przodu. Z czasem wojna oswoiła widzów i wplotła się w ramy rutyny

\footnotetext{
i znów jeszcze parę dni można było chwilowo zapomnieć o tym straszliwym widmie, które nas otacza (...). Zapominało się, że wojna wre wokoło (...). Cudowne dnie pogody bez mrozu i [pełne] ciszy w naturze, gdy tu między ludźmi taka męka.
}

Ludwika na kartach swojego dziennika nie stroni od zapisywania rzeczy zwyczajnych, nie przystających do realiów wojennych, nadmienia o: spóźnionych egzaminach, zbiorach, nabożeństwach. Postawę autorki w czasie wojny kwituje sama ona na kartce swojego kajeciku:

Wierni jesteśmy zasadzie, że póki można, pchać trzeba swoją taczkę i starać się utrzymać życie w normalnej pracy.

Nie sposób wyrwać biografii historycznej i przebiegu jej życia z uwarunkowań społeczno-gospodarczych czy politycznych epoki. Jest ona w niej osadzona i stanowi tło życiorysu, które w pamiętniku często wyczytuje się między wierszami. Sylwetka Ludwiki z Ostrowskich jest ciekawym przykładem biografistyki osadzonej w dwóch skrajnie różniących się epokach historycznych, które rozdziela burzliwy okres pierwszej wojny światowej. Wspomniane wydarzenie stało się impulsem do stworzenia pamiętnika bohaterki. Arystokratkę rodem z Maluszyna zalicza się w poczet kobiet nietuzinkowych. Sylwetka tej ziemianki wpisuje się w nurt badań nad ziemiaństwem i historią kobiet. 